\title{
Invisible Comrades: Gays and Lesbians in the Struggle
}

Brendl McClenaghan

Long Kesh

Gay men and lesbian women have been involved in the struggle for national liberation and independence as long as any other section of our people. You might claim that you have never known nor met a gay man or a lesbian women but you have met one or more today, last week, last year, 27 years ago for they have been there among us, in struggle alongside you. The primary reason you have not noticed them is that the prevailing culture in our society in relation to sexuality in general, and to homosexuality in particular, compels gays/lesbians to conform, thus their sexuality becomes invisible.

Women as a whole were also once virtually invisible in the national struggle. In recent years, however, they have argued forcefully that women's liberation must be an integral part of the struggle. In order that the concept of women's liberation be recognised and accepted as an equal, valid component, women comrades confronted their male counterparts with the contradictions of sexist words and actions. While there is still a long way to go to overcome male chauvinism and sexism, at least today, women have succeeded in putting feminist issues on the agenda of the anti-imperialist fight.

It is now time, indeed long past time, to open up debate among republicans on the issue of gays and lesbians, our oppression and its causes, and on our right to be visible equal partners. I believe that, by its very nature, national liberation incorporates gay/lesbian liberation as an integral part, and it is only through open debate leading to an understanding of gay/lesbian experience that our equality in struggle can be made a reality.

Social and economic oppression is something the people in the whole of Ireland have suffered, and in the North, the weight of British occupation is an added burden. As gays/lesbians, we are doubly oppressed, for we have had to endure further oppression within our families, local communities, and within the Republican Movement because of our sexuality. This manifests itself in many ways and affects every part of our lives.

The state discriminates against gays/lesbians and denies us equality in marriage, education, social welfare, employment, adoption, life insurance ... the list is endless. The legal status of gays/lesbians reflects attitudes in the wider society. All the churches promote traditional, stereotypical views in relation to matters like contraception, abortion, sex education for young people, and the rights of women in marriage. The Catholic Church in particular seeks to maintain its control over our lives and our sexuality, and it has spawned organisations such as family solidarity whose views on homosexuality range from the patronising and arrogant to the downright chilling: " 
If homosexual acts are legalised, the likelihood is that this will be interpreted as a major reversal in social policy, and as recognition by society that for those who are so inclined, engaging in these unnatural, unhealthy, and immoral acts is now to be seen as a right ... [Legislative reform] would send shock waves through every part of society, the structure of marriage and the family would be interfered with, the rights of children and their parents violated, and the freedom and autonomy of religious institutions and schools would be seriously breached.' (Family Solidarity News, Spring 1991)

In short, the end of civilisation as we know it because of men loving men and women loving women! Such attitudes, which are based on intolerance, misinformation, and fear, serve only to demonise gays and lesbians in the minds of Irish people, evoking images of us as depraved men and women wreaking havoc throughout society.

While oppression from the state and the institutions of society adversely affects the quality of life for gays/lesbians, there are other forms of oppression which are as much, if not more, detrimental. Gays and lesbians face oppression daily from family, comrades, neighbours, and friends due to the irrational fear of and deep prejudice against homosexuality.

The most direct expressions of such homophobia are insults, derision, and threatened or actual violence. Indirect expressions are sometimes harder to pin down but are nonetheless just as offensive: the pressures to 'be what you are but to keep it secret and don't rock the boat.' This is nothing short of moral blackmail as it is usually accompanied by comments like 'What will the family think?' or, 'It will harm the Movement/struggle.' Thus gays and lesbians are forced into invisibility within both the community and the Republican Movement, and consequently within the struggle.

This is a situation which must be confronted not only by gays and lesbians but by everyone who espouses the ideals of republicanism. 'We declare that we desire our country to be ruled in accordance with the principles of liberty, equality, and justice for all,' states the 1919 Democratic Programme of Dáil Eireann. Republicans who have always been to the fore on issues of justice and equality must begin to recognise the oppression of gays/lesbians and to identify with their needs. Republicans must acknowledge and resolve the contradictions in their attitude and behaviour which add to that oppression.

Our participation in the national liberation struggle is not a detraction from its nature and objectives; on the contrary, our involvement is a reinforcement that the struggle is indeed about the freedom and equality of all who are oppressed. No one should feel excluded. Gay men and lesbian women, especially gay/lesbian comrades within the Republican Movement, must begin the process of full integration and acceptance into the struggle by becoming more visible and making our voices heard on issues that affect us. The prejudices of others can be resolved only by confronting them and by exposing the oppression that those prejudices give rise to, with the resultant fear, 
isolation, and violence. The experience of such feelings is not imaginary; they are a daily reality for gays and lesbians in the Bogside, Falls, Monaghan, Dungannon, Ardoyne, Ballymun, Crossmaglen, and every other town and village in Ireland.

The key to gay/lesbian liberation lies in the success of the national struggle. Gays and lesbians must be a visible part of that struggle so that everyone will recognise that we fought to end the oppression of all. This vital necessity is stressed by those involved in other wars of liberation.

Simon Nkoli, a gay activist involved in the Delmas treason trial in South Africa in 1966, has this to say:

There are lots of gay activists involved in political organisations, but because of the pressure put upon the gay and lesbian community we are afraid to come out. 'What will people think if they know I'm a gay person? I'd better fight against apartheid in a hidden way.' The danger of that is that, when South Africa is liberated, we as gay people will seem never to have taken part in liberating our people. What will we say if people ask, 'What did you do to bring about change in this country, where were you during the battle?' We'd have to come back to them and say, 'We were with you but we didn't want you to know we were there.' That would be a foolish answer.

Gays and lesbians need to seek out the strength and support of each other, and of those around us who are receptive to the cause of our liberation. There is a need for gay/lesbian comrades to discuss together the issues that affect our lives and which retard participation in the national liberation struggle. In isolation, we stand alone and remain invisible, continuing to be oppressed not only by the state but within our own communities.

Through mutual reinforcement and support, we can break down the isolation that each feels and discard the cloak of invisibility that has for too long made a misery of, and destroyed, the lives of gays and lesbians. Together, we can articulate the relevance of gay/lesbian liberation, confront the homophobia that faces us, and attempt to resolve it through dialogue and discussion. This can only be based on logic and facts, not on the myths and mistruths deliberately fed to our people by those who seek to maintain control over every aspect of our lives: social, political, cultural, economic, and sexual.

Everyone has a role to play in the struggle to end all oppression. Those who are themselves oppressed have an obligation to ensure that they do not contribute in any way to the oppression of others. To do otherwise is to deny the essence of the struggle for 'liberty, equality, and justice for all.' 